\title{
Cardio-toxicity and oxidative stress induced by Egyptian Cyanobacteria Oscillatoria brevis, toxicity and mechanism of action, an in vitro study
}

\author{
Mentalla M. Mohammed ${ }^{1}$, Sherifa H. Ahmed ${ }^{2}$, Abeer S. Amin ${ }^{1}$, \\ Zohour N. Ibrahim ${ }^{3}$ and Aida A. Hussein ${ }^{4}$ \\ ${ }^{1}$ Department of Botany; Faculty of Science, Suez Canal University, Ismailia; ${ }^{2}$ Department of Zoology, Faculty \\ of Science, Port-Said University, Port Said, ${ }^{3}$ Department of Zoology, Faculty of Science, Suez Canal University, \\ Ismailia; ${ }^{4}$ Department of Zoology, Faculty of Science, Suez University, Suez, Egypt
}

\begin{abstract}
Cyanobacteria or blue green algae have become more world wide spread, Oscillatoria brevis $(O$. brevis) is one of the most toxic species collected from freshwater Suez canal during algal bloom condition and was grown in blue green medium (BG-11) under laboratory conditions. In vitro assessment of cardio-toxicity of $O$. brevis was carried out by recording Electrocardiogram (ECG) after direct perfusion of isolated toads' hearts with $5 \mu \mathrm{g} / \mathrm{ml}$ of $O$. brevis extract. Moreover, the mechanism of action of O. brevis extract on myocardium was revealed by the pharmacological tests using muscarinic receptor blocker (atropine sulfate), propranolol hydrochloride and verapamil. Oxidative stress induced by $O$. brevis was estimated by incubation of mice blood with $1 \mu \mathrm{g} / \mathrm{ml}$ of $\mathrm{O}$. brevis at $37^{\circ} \mathrm{C}$ for 2, 4, 6, 8 and 24 hours respectively to determine the level of lipid peroxidation and antioxidants activities. Perfusion of isolated toads' hearts with $5 \mu \mathrm{g} / \mathrm{ml} O$. brevis extract significantly decreased the heart rate with an increase in the conduction time (P-R interval). Also, a remarkable increase in the power of ventricular contraction was observed, It was suggested that $O$. brevis could act through $\mathrm{Ca}^{2+}$ channels where verapamil application abolished the increase in myocardial contractility noticed after 10 minutes of $O$. brevis extract application. Lipid peroxidation and blood catalase activity significantly increased while a pronounced decline of blood glutathione concentration and erythrocyte superoxide dismutase activity were noticed. Oxidative stress induced by $O$. brevis could underlying the cardiotoxicity which is represented by sinus arrhythmia, ectopic beats and heart infarction.
\end{abstract}

Key word: $O$. brevis, ECG, Heart rate, $\mathrm{Ca}^{2+}$ channels, oxidative stress.

\section{Introduction}

Cyanobacteria or blue green algae have become more world wide spread (Paerl, 2007). Which inhabitants of fresh, brackish and marine, Over forty species of freshwater cyanophytes have been implicated in toxic blooms, Microcystis, Oscillatoria, Anabaena, Nostoc which are the most toxic species water (Whitton \& Potts, 2000). Harmful produced toxins are secondary metabolites known as cyanotoxins, are classified according to their toxicity into neurotoxins, hepatotoxins and skin irritants (Carmichael, 1997). Cyanotoxins are toxic to mammals and aquatic invertebrates. Sheep were died following ingestion of cyanobacterial polluted water (Krienitz et al., 2003). Since this was published many others have shown that toxic cyanobacteria can also intoxicate mammals, waterfowl and fish. Humans are also found to be intoxicated by cyanobacteria, either due to accidental ingestion of water during, for example, aquatic sports or following ingestion of drinking water contaminated with toxic cyanobacteria (Gehringer, 2003). Some species of Oscillatoria are toxic to human and animals, and are known to produce both neurotoxins (anatoxin) and hepatotoxin (microcyctins) (Hisbergues et al., 2003). Anatoxins can block the transmission of signals from neuron to neuron and from neuron to muscle, where microcystins cause bleeding in the liver (observed in mice after i.p. injection with Oscillatoria brevis extract (El-Manawy \& Amin, 2004a).

Intravenous and intra-cerebro-ventricular administration of anatoxin-a resulted in an increase in mean arterial pressure (MAP), in the conscious rat with concomitant bradycardia (Sirén and Giora, 2004 \& Madigan et al., 2000). Moreover, Guzman and Solter (2002) reported that IP administration of MC-LR into young male rats resulted in a decrease in body weight concomitant with a significant increase of ALP, AST, ALT, and GGT activities and elevated levels of BUN and creatinine. Fitzgeorge et al, (1994) investigated the co-effect of anatoxin-a toxicity with microcystin-LR, the most common cyano-hepatotoxin. They found a significant synergistic effect between anatoxin-a and microcystin-LR.

Gomaa et al., 2000 indicated Oscillatoria brevis is a taxic cyanobacterium in Egypt. Amin (2001) reported acute neurotoxicity signs in mice after i.p injection with extract of $O$. brevis collected from Port Said freshwater canal during bloom condition. A bloom of Microcystis aeurginosa and Oscilltoria species have been 
reported in Suez governorate in 2003, 2004 associated with the emergency obnoxious taste and odor in drinking water (El-Manawy \& Amin, 2004a).

The current study was conducted to investigate the influence of $O$. brevis on the electrical activity of isolated heart and its potential to cause adverse health effects by induction of oxidative stress.

\section{Sample collection, culture and extraction of toxin \\ II. Material And Methods}

The phytoplankton samples were collected seasonally from freshwater Suez canal, Suez, Egypt, from five stations in the canal during a period of 12 months. Species of phytoplankton were identified using the inverted microscope (Prescott, 1978). Stock algal bloom was maintained in BG-11medium for growth and toxin production, at room temperature supplied by sterilized air (Carmichael, 1985). An HPLC system used 600E pump system was used for lyophilized filtrate purification steps.

\section{Chemicals and solutions}

Atropine sulphate was purchased from Memphis Co, Dorpharm and Chem, Ind. Cairo, Egypt. Where concentration of $4 \mu \mathrm{g} / \mathrm{ml}$ Ringer solution was used on heart preparations. Verapamil hydrochloride (40 $\mathrm{mg})$, the calcium channel blocker was used on the heart with a dose of $5 \mu \mathrm{g} / \mathrm{ml}$ of Ringer solution. It was purchased from ADWIC pharmaceutical division, EL Nasr Pharm. Chem. Co., Abu Zabal, Egypt. Propranolol was bought from Sigma Co. and was used in experiments on the heart with a final concentration of $5 \mu \mathrm{g} / \mathrm{ml}$ Ringer solution. The concentration of the blockers (atropine sulphate, verapamil and propranolol) used in the present work were applied according to Nabil et al. (1998).

\section{Experimental animals}

Adult male toads (Bufo regularis) were used as an experimental model for in vitro experiments. Also, male adult albino Mice weighting 25-33g were used in this study. Animals were housed under standardized conditions and allowed free access to food and water ad libitum and left for acclimatization before the start of the study.

\section{Cardiac muscle experiments}

Experiments on cardiac muscle were carried out on adult of isolated heart male toads (35-40 g each). Four groups of toads of ten animals of each group were used, the first group was directly perfused with $5 \mu \mathrm{g} / \mathrm{ml}$ of $O$. brevis extract to study the electrical effects of $O$. brevis on the ECG. ECG data were recorded directly from the surface of the heart according to Nabil et al. (1998) before and after O. brevis application. ECG was taken before any application to serve as self control. After $O$. brevis perfusion, signals were recorded each 5 min for $30 \mathrm{~min}$. Atropine sulphate, verapamil and propranolol, were applied after $10 \mathrm{~min}$ (the time in which the pronounced effect of $O$. brevis was recorded in all toxicological experiments) to reveal the mechanism of action on heart preparations $(n=5)$.

\section{Oxidative stress biomarkers}

Mice were divided into 2 groups (10 mice /group) for biochemical study, the $1^{\text {st }}$ group served as control where mice were slaughtered and blood samples were collected, EDTA $(50 \mu 1)$ was added to all blood samples before incubation as an anticoagulant. Blood of the $1^{\text {st }}$ group was incubated with $1 \mathrm{ml}$ of the vehicle $(0.9 \% \mathrm{NaCl})$ to serve as control, while blood of the $2^{\text {nd }}$ group was incubated with $1 \mu \mathrm{g} / \mathrm{ml}$ of $O$. brevis at $37{ }^{0} \mathrm{C}$ for $2,4,6,8$ and 24 hour respectively. Samples of the whole blood were used for determination of glutathione and catalase according to the methods of (Beutler et al 1963 and Aebi, 1984), while superoxide dismutase (SOD) was measured in erythrocytes according to (Winterbourn et al., 1975). On the other hand, lipid peroxidation was estimated in serum of control and treated blood samples (Sharma and Wadhwa, 1983)

\section{Statistical Analysis}

The results were expressed as means \pm S.E. Changes in the heart rate (HR) and the other ECG parameters of isolated toads' hearts after $O$. bervis extract or antagonist application were tested for the statistical significance using paired t-test (Snedecor, 1980) at $\mathrm{P}<0.05, \mathrm{P}<0.01$ and $\mathrm{P}<0.001$. Percentage of change (\%) of electrocardiographic parameters of toads was expressed of the raw data before and after $O$. bervis extract application. Changes in the concentration of lipid peroxidation, GSH, catalase and SOD were tested using unpaired t-test to determine the difference of treatment from control group (Snedecor, 1980) at $\mathrm{P}<0.05, \mathrm{P}<0.01$ and $\mathrm{P}<0.001$. 


\section{Electrophysiological results}

\section{Results}

In vitro experiments were accomplished to investigate the effect of the $O$. brevis extract on myocardium activity. ECGs were recorded from isolated toads hearts before and after perfusion of $O$. brevis. Normal heart rate (HR) and different ECG parameters were measured from the recorded electrocardiograms of isolated hearts before any treatment to serve as self-control (0-time). The effects of direct perfusion of $O$. brevis on the HR, conduction time ( $\mathrm{P}-\mathrm{R}$ interval), depolarization and repolarization voltage ( $\mathrm{R}$ and $\mathrm{T}$ wave) of the isolated hearts are summarized in Table1. Direct perfusion of isolated toad's heart with $0.5 \mu \mathrm{g} / \mathrm{ml} \mathrm{of} O$. brevis extract on the heart rate induced negative chronotropic effects (bradycardia) represented by a highly significant decrease of heart rate at different time intervals $10,15,20,25,30 \mathrm{~min}(\mathrm{P}<0.001)$. Bradycardia was accompanied with a significant negative dromotropic effect represented as an elongation of P-R interval of the recorded ECG at all the recorded times $(\mathrm{P}<0.001)$. This indicates a decrease in the conduction velocity of impulses as shown in table 1 and Plate1.

A remarkable increase in the ventricular amplitude of contraction was noticed after direct perfusion of $0.5 \mu \mathrm{g} / \mathrm{ml} \mathrm{O}$. brevis extract on the isolated toad's heart indicated by a significant increase in the R-amplitude at different time intervals 10,15, 20, 25, 30 min from toxin application $(\mathrm{P}<0.01)$. Also, application of $0.5 \mu \mathrm{g} / \mathrm{ml}$ $O$. brevis extract on isolated toad's heart induced an increase in the ventricular repolarization voltage since a significant increase in the T-amplitude after different time intervals 10, 15, 20, 25, 30 min was noticed $(\mathrm{P}<0.01)$ compared to self control as seen in table 1 .

The percentage of change of the heart rate, P-R interval, depolarization voltage and repolarization voltage of the isolated toad's heart following $O$. brevis toxin perfusion within 30 minutes are represented in fig. 1 $\mathrm{A}, \mathrm{B}, \mathrm{C}$ and D.

Furthermore, ECGs charts have shown examples of cardiac disorders induced by direct application of O. brevis extract on isolated toads' hearts (plate. 2) such as Wide QRS-Wave, Sinus arrhythmia, ST-depression and First degree block, Peaked P- wave, Ectopic beats, Negative QRS deflection, Second degree block and Complete heart block. Table 2 represents percentage of cardiac disorders incidents, as seen in the table 2, sinus abnormalities were the most frequent followed by different degree of atrioventricular blocker.

\section{Mechanism of action of $\boldsymbol{O}$. brevis extract on the cardiac muscle activity}

In an attempt to reveal the mechanism of action of $O$. brevis extract on the cardiac muscle activity, $4 \mu \mathrm{g} / \mathrm{ml}$ of atropine sulfate was used as muscarinic receptor antagonist, to ameliorate the decline in the heart rate and atrioventricular conduction velocity induced by $O$. brevis extract, post treatment with atropine sulfate did not abolish the negative chrono and dromotropic effect of $O$. brevis extract (plate3).

On the other hand, the $\beta$ adrenergic bloker propranolol hydrochloride $(5 \mu \mathrm{g} / \mathrm{ml})$ as well as verapamil $(5 \mu \mathrm{g} / \mathrm{ml})$ as a selective antagonist L- type $\mathrm{Ca}^{2+}$ channels were used following perfusion of $O$. brevis extract, to suppress the pronounced increased of myocardial contractility. Propranolol could not abolish the positive inotropic effect, while verapamil application could inhibit the noticed increase in myocardial contractility after 10 minutes of $O$. brevis extract application. Fig.2. Plate 3 illustrates an action of $O$. brevis mechanism after atropine, propranolol and verapamil application on the isolated heart.

\section{Oxidative stress biomarkers}

Incubated of blood with $O$. brevis extract with a concentration of $1 \mu \mathrm{g} / \mathrm{ml}$ for $2,4,6,8,24 \mathrm{hrs}$ significantly increase plasma lipid peroxidation represented by an increase in thiobarbituric acid reactants (TBARS) level with percentage of change $88,91,91,82,81 \%$ compared to control group.

Furthermore, a pronounced decline of blood glutathione concentration was noticed after 2, 4, 6, $8 \mathrm{hrs}$ of O. brevis extract incubation with percentage of change 7.3, 19.2, 12.2, 11\% compared to control group. After $24 \mathrm{hrs}$ of incubation time, a remarkable increase was noticed with a percentage of change $9.9 \%$ compared to control group. In the mean time, the activity of blood catalase increased after 4 and 6 hours of incubation with $1 \mu \mathrm{g} / \mathrm{ml}$ of $O$. brevis extract.

On the other hand, $O$. brevis extract significantly decreased erythrocytes superoxide dismutase activity with a percentage of change $82,84,106,174,155 \%$ compared with control group in all incubation times. The effect of $O$. brevis extract on plasma lipid peroxidation, blood glutathione, catalase and SOD activities are represented in fig.3. 


\section{Discussion}

In vitro experiments were carried out in the current study on the isolated perfused toad's heart, since isolated organ preparations offer several advantages over experimentation on the intact animals because they lend themselves to a definite evaluation of the role of a particular organ or tissue in the disposition of endogenous or exogenous chemicals (Mehendale, 1984).

ECGs were recorded from isolated toad's hearts that were directly perfused with $5 \mu \mathrm{g} / \mathrm{ml}$ of $O$. brevis extract where it had pronounced effects on the myocardial activity. Negative chronotropic and dromotropic effects were noticed after $O$. brevis extract application, indicating a significant decrease in the heart rate (bradycardia) accompanied by an elongation of the P-R interval indicating increasing of conduction time. In the mean time, a positive inotropic effect represented as an increase in the $\mathrm{R}$ wave amplitude was recorded after 10 minutes of $O$. brevis application of the used dose, indicating an increase in the force of ventricular contraction.

In an attempt to reveal the mechanism of action of $O$. brevis extract, application of verapamil, a selective antagonist of L-type $\mathrm{Ca}^{2+}$ channels, has completely abolished the positive inotropic activity induced by $O$. brevis extract indicating a direct effect of $O$. brevis extract on the $\mathrm{Ca}^{+2}$ channels of myocardial fibers. Neither, atropine as a muscarinic cholinergic antagonist, nor propronolol could abolish the negative chrontropic and inotropic effects, which approved the above mentioned notice about the direct myogenic effect on the myocardium and exclude a neurogenic mechanism of action of the toxin (Nabil et al., 2004).

The positive inotropic effects as well as negative chronotropic and dromotropic actions of $O$. brevis extract on the heart might be result of binding to and inhibition of sarcolemmal $\mathrm{Na}^{+}-\mathrm{K}^{+}$ATPase. However, Inhibition of the $\mathrm{Na}^{+}$pump causes an intracellular accumulation of $\mathrm{Na}^{+}$, thus reducing $\mathrm{Ca}^{2+}$ removal from cytoplasm and/ or promoting reverse mode of $\mathrm{Ca}^{2+}$ influx via the $\mathrm{Na}^{+} / \mathrm{Ca}^{2+}$ exchanger. This subsequently leads to an increase in $\mathrm{Ca}^{2+}$ accumulation in the sarcoplasmic reticulum (SR) inducing positive inotropic effect and causing SR $\mathrm{Ca}^{2+}$ overload in the case of toxicity(Lee, 1985).

Calcium ions are the most versatile ionic messengers. Where, stimulation of the outer surface of a muscle cell triggers thousands of $\mathrm{Ca}^{2+}$ releases from SR into the cytosol that increases intracellular calcium levels, creating a $\mathrm{Ca}^{2+}$ signal which activates calcium-sensitive proteins which in turn causes contraction of myofilaments via binding to the troponin component, this in turn results in a positive inotropic action (Silverthorn et al., 2010). Excessive calcium concentration in the cell may damage it or even cause it to undergo apoptosis or death by necrosis, associated with cardiac arrhythmias (Boron et al., 2003).

It was evidence that sinus abnormalities were the most frequent disorders followed by different degrees of Atrioventricular blocks reported after direct perfusion of isolated toad's heart with $5 \mu \mathrm{g} / \mathrm{ml} O$. brevis extract. This indicates that the toxic myogenic effects on the myocardium are mostly directed to both Sinoatrial (SA) and atrioventricular (AV) nodes. Furthermore, striking effects on ECG were noticed taken from perfused isolated toad's heart as a group of cardiac disorders. These pathologic cases included S-T segment depression, sinus arrhythmia, severe bradycardia, heart block and ectopic beats, which are often a feature of myocardial infarction (Julian et al., 2000 and Hussein, 2003). These observations confirm the direct mechanism of action of O. brevis toxin (Mohammed et al., 2011).

The mechanism of toxicity of many compounds requires formation of ROS, including superoxide anion, hydrogen peroxide, superoxide radicals and hydroxyl radical. Reactive oxygen species (ROS) are formed and degraded by all aerobic organisms, leading to either physiological concentrations required for normal cell function, or excessive quantities, the state called oxidative stress (Silverthorn et al., 2010). They are capable to react with proteins, nucleic acids, lipids and or other molecules leading to changes in their structures and consequently damage of cells. Fortunately, the cells are able to protect themselves against oxidative stress, as they develop numerous defensive mechanisms based on the antioxidative enzymes activity and action of low molecular antioxidants such as glutathione (Mates, 2000).

As lipid peroxidation (LPO) and oxidative stress play a key role in the pathogenesis of many diseases, the effect of $O$. brevis extract as free radical inducer was evaluated through their effect on lipid peroxidation (TBA reactants), endogenous antioxidants and morphological of erythrocyte, through in vitro study.

Marked changes were observed on lipid peroxidation, activity of antioxidants (GSH, CAT and SOD), in blood after in vitro incubation with $1 \mu \mathrm{g} / \mathrm{ml} O$. brevis extract. However, a significant increase in thiobarbituric acid reactive substances (TBARS) concentration after incubation with $O$. brevis extract was noticed. This indicates that membrane lipids were attacked by reactive oxygen species to form a carbon radical that reacts with free radical and results in a peroxyl radical, thus generating lipid peroxides (Domenico et al., 2000). In the mean time, imbalances in antioxidant defense as the consequence of increase of free radical generation stimulated by $O$. brevis extract were reported by (Fayun, et al., 2007 \& Pasupathi et al., 2009 and Mohammed et al., 2010). This observation is in agreement with the changes caused by microcystin-LR (MC-LR) and anatoxina on LPO level and antioxidants (Mitrovic et al., 2004).

Glutathione (GSH) is the most abundant intracellular thiol-based antioxidant, prevalent in millimolar concentrations in all living aerobic cells. Its function is mainly as a sulfhydryl buffer, but GSH also serves to 
detoxify compounds either via conjugation reactions catalyzed by glutathione S-transferases (Armstrong, 1997) or directly, as is the case with hydrogen peroxide in the glutathione peroxidase (GPx) catalyzed reaction (Van Bladeren, 2000). GPx may catalyze the reduction of $\mathrm{H}_{2} \mathrm{O}_{2}$ using glutathione as a substrate (Mates et al., 1999).

In the current study, imbalanced changes in GSH level were noticed. However, a decrease in GSH level followed by an increase is correlated with different time and dose treatment. GSH depletion could be related to its involvement in the detoxification of the deleterious effects of the increase free radicals produced within the cell (Moussa, 2009 and Nabil et al., 2006). Then, Increases in the level of GSH can play a critical role in the protection of cells from oxidative stress. However, the capacity to increase GSH synthesis in response to increased demands on GSH utilization is thought to be an important determinant of cell survival (Maher, 2005). This observation coincides with Halliwell and Gutteridge (1993) who observed that although severe oxidative stress, which is defined as an imbalance between the production and removal of reactive oxygen species, can cause a decrease in GSH were a number of reports have shown that moderate stress often increases GSH. This increase is likely to provide protection of cells from both the ongoing stress and from subsequent, more severe stress.

Many compounds initially decrease GSH levels before eventually leading to an increase well above control levels (Maher, 2005). However, treatment with compounds that decrease GSH can lead to a transient increase in GSH levels. This observation coincides with Maher (2005) who noticed that the increase in GSH levels correlates in a time and dose dependent fashion with an increase in the level of Glutamate cysteine ligase (GCL) which catalyzes the first and rate-limiting step in GSH biosynthesis (Dickinson et al., 2004)

It is well know that, catalase and superoxide dismutase are able to scavenge reactive oxygen species (ROS) such as the superoxide anion and strong oxidant hydrogen peroxide (Sicin'ska et al., 2006\& Reiter et al., 2000). Catalases of many organisms are mainly heme-containing enzymes (Quick et al., 2008). The predominant subcellular localization in mammalian cells is in peroxisomes, where catalases catalyze the dismutation of hydrogen peroxide to water and molecular oxygen (Halliwell, 1999)

Moreover, a significant increase in catalase activity after incubation of $1 \mu \mathrm{g} / \mathrm{ml}$ O.brevis extract for 4 and 6 hours was noticed. This observation is in agreement with Qiu et al., (2009) who proved that microcystinLR induced oxidative stress by increasing lipid peroxidation and activity antioxidants (CAT and SOD) after I.V administration in rats. Sicin'ska et al., (2006) noticed that no change was observed on catalase activity after incubated human blood with low doses of microcystin-LR on human blood for 1, 6, 12, 24 hours.

On the other hand, the present in vitro study revealed that erythrocyte SOD activity highly declined after treatment with $\mathrm{O}$. brevis extract compared with control group coinciding with that noticed in the in vivo experiments (Mohammed et al., 2011). SOD converts superoxide anion radicals produced in the body to hydrogen peroxide. SOD activity may be decreased either due to direct damage of protein structure by $O$. brevis extract or could be consumed by increasing amount of hydrogen peroxide (Sicin'ska et al., 2006). Disturbance in removal of superoxide radical provokes further damage of the SOD enzyme and causes the increase of the level of $\mathrm{H}_{2} \mathrm{O}_{2}\left(\mathrm{O}^{\prime \prime}\right.$ ztu"rk and Gu"mu"s, lu", 2004). The above mentioned results confirm the previous work of Sicin'ska et al., (2006) who noticed that Microcystin-LR decreased the activity of SOD and increased lipid peroxidation in blood samples. On the contrary, Mitrovic et al., (2004) showed that anatoxin-a increased catalase activity and caused formation of reactive oxygen species, increased SOD activity and slightly increased lipid peroxidation. Accordingly, it can be concluded here that $O$. brevis toxin extract induced a disturbance in antioxidants system and increased lipid peroxidation consisting in oxidative stress.

The oxidative stress resulted from ROS generation can lead to a decrease in calcium responsiveness of myofilaments either directly by oxidative modification of contractile protein, or indirectly, by causing $\mathrm{Ca}^{2+}$ overload. There are at least two mechanisms whereby ROS can produce calcium overload: i) ROS can promote sarcolemmal damage, with consequent loss of selective permeability, impairment of calcium- stimulated ATPase activity and calcium transport out of cell, and ii) ROS can impair calcium stimulated ATPase activity and calcium transport in the sarcoplasmic reticulum, resulting in decreased calcium sequestration and increased free cytosolic calcium (Bolli and Marban, 1999).

In addition, enhanced lipid peroxidation may affect the lipid moiety of one or more of the subcellular organelles that contribute to the process of contraction other than those affecting $\mathrm{Ca}^{2+}$ homeostasis and increased free cytosolic calcium (Jamall,1987). These suggestions may offer an explanation of cardiotoxicity induced by $O$. brevis extract in isolated toad's heart with significant negative chronotropic and dromotropic effect on atrioventricular conduction system and stimulatory inotropic effect of ventricular contraction. An in vivo study might be needed to confirm these suggestions.

\section{Acknowledgment}

The authors wish to express their deep appreciation to Prof. Mohammed Naser, Prof. of the marine toxins at National Researches Centre, Egypt for providing the facilities to accomplish this work . 


\section{References}

[1]. Aebi, H., 1984. Catalase in vitro. In: Packer, L. (Ed.), Methods in enzymology, Academic Press, Orlando. 105, 121-126.

[2]. Amin, A. S., 2001.Distribution pattern of freshwater algae and their toxins in raw and municipal water in port said province. Ph.D. thesis Bot. Dep., Fac. Of Sci., Suez canal Univ.116pp.

[3]. Armstrong, R. N. 1997. Structure, catalytic mechanism, and evolution of the glutathione transferases. Chem. Res. Toxicol. 10, 218.

[4]. Beutler, E., Doran, O. and Kelly, B., 1963. Improved method for the determination of blood glutathione. J. Lab. Clinic Med., 61, $882-888$.

[5]. Bolli, R. and Marban, E., 1999. Molecular and cellular mechanisms of myocardial stunning. Physiological reviews, 79, 609-634.

[6]. Boron, Walter, F., Boulpaep, and Emile, L., 2003. Medical Physiology: A Cellular and Molecular Approach. Elsevier. 867, 41602328.

[7]. Carmichael, W.W., 1985. Isolation, culture and toxicity testing of toxic fresh water cyanobacteria (Blue green algae) ISHC Symposium, Leningrad, USSR, Gordon and breach, New York.

[8]. Carmichael, WW, 1997. The cyanotoxins. In: Callow JA [ed.], Advances in botanical research, 37,211-256.

[9]. Dickinson, D. A., Levonen, A. L., Moellering, D. R., Arnold, E. K., Zhang, H., Darley-Usmar, V. M. and Forman, H.J., 2004. Human glutamate cysteine ligase gene regulation through the electrophile response element. Free Radic. Biol. Med. 37, $1152-1159$.

[10]. Domenico, P., Norman, M. D. and Mrcpi, M. B., 2000. Oxidative Injury in Diseases of the Central Nervous System: Focus on Alzheimer's Disease. J Med. 109,577-585.

[11]. El-Manawy, E. M., and Amin. A. S., 2004a. Factors controlling the phytoplankton community in port said freshwater canal. $4^{\text {th }}$ Int. Conf. Biol, Tanta Unit. 2, 144-156.

[12]. Fayun, L.I., Liangliang, J.I., Luoandi, Y.I. and Kokyo, O.H., 2007. Hydroxyl radical generation and oxidative stress in Carassius auratus liver, Chemosphere, 67, 13-19.

[13]. Fitzgeorge, R. B., Clark S. A. and Keevil, C.W., 1994. Routes of intoxication. In: G.A. Codd, T.M. Jeffries, C.W. Keevil and E. Potter, Editors, Proceedings of the first international symposium on detection methods for cyanobacterial (blue-green algal), Royal Society of Chemistry, 69-74.

[14]. Gehringer, M. M., Kewada, V., Coates, N., and Downing, T.G., 2003. The use of Lepidium sativum in a plant bioassay system for the detection of microcystin- LR. Toxicon 41, 871-876.

[15]. Gomaa, M. N., El-Manawy, I. M. and Amin, A. S., 2000. Neurotoxicity from freshwater Oscillatoria brevis (Kutz.)in port-Said, Egypt.J.Egypt.Soc. Toxicol., 23, 9-15.

[16]. Halliwell. B., Gutteridge. J.M.C., 1998. Free Radicals in Biology and Medicine. Oxford, UK: Clarendon Press. Free radicals, other reactive species and disease, pp. 617-783

[17]. Halliwell, B., 1999. Antioxidant defense mechanisms: from the beginning to the end. Free Radic. Res. 31:261-272.

[18]. Hisbergues, M., Christiansen, G., Rouhiainen, L., Sivonen, K., and Borner, T., 2003. PCR-based identification of microcystinproducing genotypes of different cyanobacterial genera. Arch Microbiol.180, 402-10.

[19]. Hussein, A. A., Rakha, M. A. and Nabil, Z. I., 2003. Anti arrhythmic effect of wild honey against catecholamines cardiotoxicity. J.Med. Sci., 3(2), 127-136.

[20]. Jamall, I.S., 1987. Differential effects of cadmium on cytosolic and mitochondrial glutathione levels in the rat heart. FEBS-Lett. 214(1), 62-64.

[21]. Julian, D., Cowan, J. and Mclenachan, J., 2000. Heart failure In: "Cardiology" International Edition, Harcourt Publishers Ltd. North Youkshire, China. Pp. 129-153.

[22]. Krienitz, L., Ballot, A., Kotut, K., Wiegand, C., Pütz, S. and Metcalf, S., 2003. Contribution of hot spring cyanobacteria to the mysterious deaths of Lesser Flamingos at Lake Bogoria, Kenya, FEMS Microbiol Ecol pp. 43,141-148.

[23]. Madigan, M.T., Martinko, J.M. and Parker, J., 2000. Brock Biology of microorganisms $9^{\text {th }}$ edition. Prentice Hall. Upper Saddle River, NJ. 991, 13-9780130819222.

[24]. Maher, P., 2005. The effects of stress and aging on glutathione metabolism. Ageing Research Reviews. 4 , $288-314$.

[25]. Mates, J. M., Perez-Gomez, C. and Nunez de Castro, I., 1999. Antioxidant enzymes and human diseases. Clin. Biochem. 32,595603 .

[26]. Mehendale, H. M., 1984. Application of isolated organ technique in toxicology. In: Principles and methods of toxicology, Hayes A W. (ed). Raven Press, New York.

[27]. Mitrovic, S.M., Pflugmacher, S., James, K.J. and Furey, A., 2004. Anatoxin-a elicits an increase in peroxidase and glutathione Stransferase activity in aquatic plants. Aqua. Toxicol. 68, 185-192.

[28]. Mohammed, M. A; Ahmed, S. H.; Amin, A. S.; Nabil, Z. I. and Hussein, A.A., 2011. Oxidative stress induced by Suez fresh water canal cyanobacterial Oscillatoria brevis (Kütz.) toxin. Egyptian journal of Natural Toxin. 8,16-31.

[29]. Moussa, S. A., 2009. Oxidative stress in rats exposed to microwave radiation. Romanian J. BIOPHYS., P. $149-158$.

[30]. Nabil, Z. I., Hussein, A.A., Zalat, S.M. and Rakha, M.A., 1998. Mechanism of action of honey bee (Apis Meeifera L.) venom on different types of muscles. Human \& Experimental Toxicology 17, 185-190.

[31]. Nabil, Z. I., Hussein, A.A., Omran, M.A., Youssef, A.M. and Ahmed, S.H., 2004. Effect of aerial parts of Calotropis procera on the muscle activity (in vitro study). Accepted and represented in the $20^{\text {th }}$ Anniversary Conference of the Egyptian Society of Toxicology. Bibliotheca Alexandria, 18-19.

[32]. Nabil, Z. I., Hussein, A.A., Youssef, A.M., Ahmed, S.H. and Omran, M.A., 2006. Assessment of the therapeutic effect of Calotropis procera extract compared to digoxin on myocardial pathophysiology: an experimental study. Egyptian Journal of Natural Toxins, Vol. 3, 51-76.

[33]. O" ztürk, O., Gu"mu“s, lu, S., 2004. Changes in glucose-6phosphate dehydrogenase, copper, zinc-superoxide dismutase and catalase activities, glutathione and its metabolizing enzymes, and lipid peroxidation in rat erythrocytes with age. Exp. Gerontol. 39, 211216.

[34]. Paerl, H.W., 2007. Nutrient and other environmental controls of harmful cyanobacterial blooms along the freshwater-marine continuum. In, H. K. Hudnell (Ed.) Proceedings of the Interagency, International Symposium on Cyanobacterial Harmful Algal Blooms. Advances in Experimental Medicine and Biology, Ch. 10, 215-241.

[35]. Pasupathi, P., Yagneswara Y.R., Farook, J., Saravanan, G., Bakthavathsalam,G., 2009. Oxidative Stress and Cardiac Biomarkers in Patients with Acute Myocardial Infarction. European Journal of Scientific Research. pp. 275-285.

[36]. Prescott, G.W., 1978. How to Know Freshwater Algae, (3 ${ }^{\text {rd }}$ Ed.), P, 293.The Pictured Key Nature Series USA

[37]. Qiu, T., Xie P., Liu, Y., Li, G., Xiong, Q., Hao, L. and Li, H., 2009. The profound effects of microcystin on cardiac antioxidant enzymes, mitochondrial function and cardiac toxicity in rat . Elsevier. 257, 86-94. 
[38]. Quick, K., Shields, G., Nie, J., Platek, E, Cann, E., Hutson, D., Trevisan and Freudeheim, L., 2008. Effect modification by catalase genotype suggests a role for oxidative stress in the association of hormone replacement therapy with postmenopausal breast cancer risk. Cancer Epidemiol Biomarker prev, 17(5), 1082-1087

[39]. Reiter, J., Tan, X., Osuna, C., and Gitto, E., 2000. Action of melatonin in the reduction of oxidative stress. A review journal of Biomedical Science, 7(6),444-458.

[40]. Sharma, S. P., and Wadhwa, R., 1983. Effect of Butylated hydroxyl touene on the life span of Drosophila Bipeotinata. Mechanism of ageing and development, 23, 67-74.

[41]. Sicin'ska, P., Bukowska, B., Michałowicz, J., and Duda, W., 2006. Damage of cell membrane and antioxidative system in human erythrocytes incubated with microcystin-LR in vitro. Toxicon $47,387-397$.

[42]. Silverthorn, D.U., Johnson, B. R., Ober, W. C., Garrison, C.W and Silverthorn, A. C., 2010. Cardiovascular physiology. In Human physiology: an integrated approach. $5^{\text {th }}$ ed, Boston New York, 468-504.

[43]. Sirén, A. and Giora, F., 2004. Cardiovascular effects of anatoxin-A in the conscious rat. USA. Toxicology, Volume 102, $91-100$.

[44]. Snedecor, G.W., 1980. Statistical methods. $7^{\text {th }}$ ed. Iowa State Univ.press. Ames, Iowa U.S.A.

[45]. van Bladeren, P. J., 2000. Glutathione conjugation as a bioactivation reaction. Chem. Biol. Interact. 129,61-76.

[46]. Wang, S.O., Song, L.S., Laktta, E.C. and cheng, H. 2001. $\mathrm{Ca}^{2+}$ signaling between single L-tube Ca ${ }^{2+}$ channels and ryanodine receptors in heart cells. Nature 410, 592-596.

[47]. Whitton, B.A., and Potts, M., 2000. Introduction to cyanobacteria, in: Whitton B.A., Potts M. (Eds.), the ecology of cyanobacteria, Kluwer Academic Publishers, Dordrecht, pp. 1-11.

[48]. Winterbourn, C., Hawkins, R.E., Brian, M. and Carrell, R.W., 1975.The estimation of red cells Superoxide dismutase activity. J. Lab. Clin med. 85, 337-43.

Table 1 Effect of direct perfusion with $(5 \mu \mathrm{g} / \mathrm{ml})$ O. brevis extract on the heart rate (HR), conduction time $(\mathrm{P}-\mathrm{R}$ interval), amplitude of ventricular contraction (R-amplitude), and repolarization voltage (T-amplitude) of isolated toad hearts

\begin{tabular}{ccccc}
\hline Time (min) & Heart rate (beat/min) & P-R interval (msec) & R- Amplitude (mV) & T- Amplitude (mV) \\
\hline 0 & $53.1 \pm 1.6$ & $420 \pm 13.3$ & $1.94 \pm 0.09$ & $0.82 \pm 0.19$ \\
$5 \mathrm{~min}$ & $49.6 \pm 1.4^{¥}$ & $490 \pm 17.9^{¥}$ & $2.5 \pm 0.18^{\S}$ & $0.92 \pm 0.11$ \\
$10 \mathrm{~min}$ & $45.6 \pm 1.7^{¥}$ & $560 \pm 16.3^{¥}$ & $2.84 \pm 0.29^{\S}$ & $1.38 \pm 0.13^{\S}$ \\
$15 \mathrm{~min}$ & $42.7 \pm 0.8^{¥}$ & $630 \pm 21.3^{¥}$ & $2.82 \pm 0.22^{\S}$ & $1.64 \pm 0.17^{\S}$ \\
$20 \mathrm{~min}$ & $41.4 \pm 0.9^{¥}$ & $650 \pm 26.8^{¥}$ & $2.66 \pm 0.23^{\S}$ & $1.77 \pm 0.19^{\S}$ \\
$25 \mathrm{~min}$ & $39.5 \pm 1.3^{¥}$ & $740 \pm 30.6^{¥}$ & $2.44 \pm 0.22^{*}$ & $1.6 \pm 0.18^{\S}$ \\
$30 \mathrm{~min}$ & $37.2 \pm 1.2^{¥}$ & $750 \pm 37.3^{¥}$ & $2.3 \pm 0.24$ & $1.56 \pm 0.2^{*}$ \\
\hline
\end{tabular}

Values expressed as mean \pm SE ( $\mathrm{n}=10$ /group).

Significantly different between self control (0- time) and treated groups $(5,10,15,20,25$ and 30 min) using Student's paired t-test. $*(\mathrm{P} \leq 0.05), \S(\mathrm{P} \leq 0.01), ¥(\mathrm{P} \leq 0.001)$.
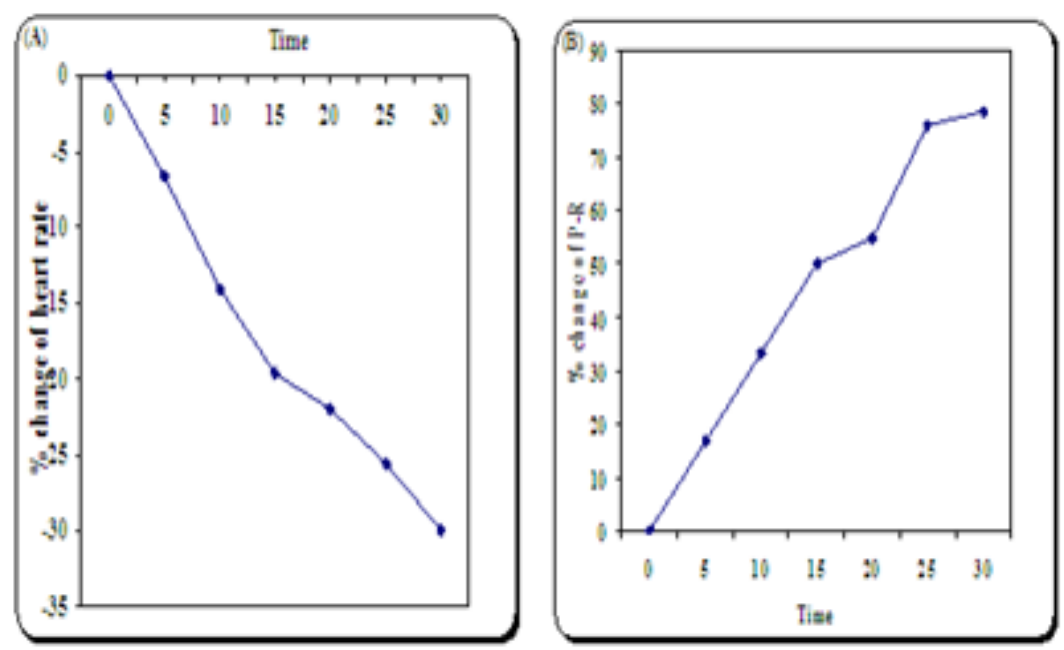

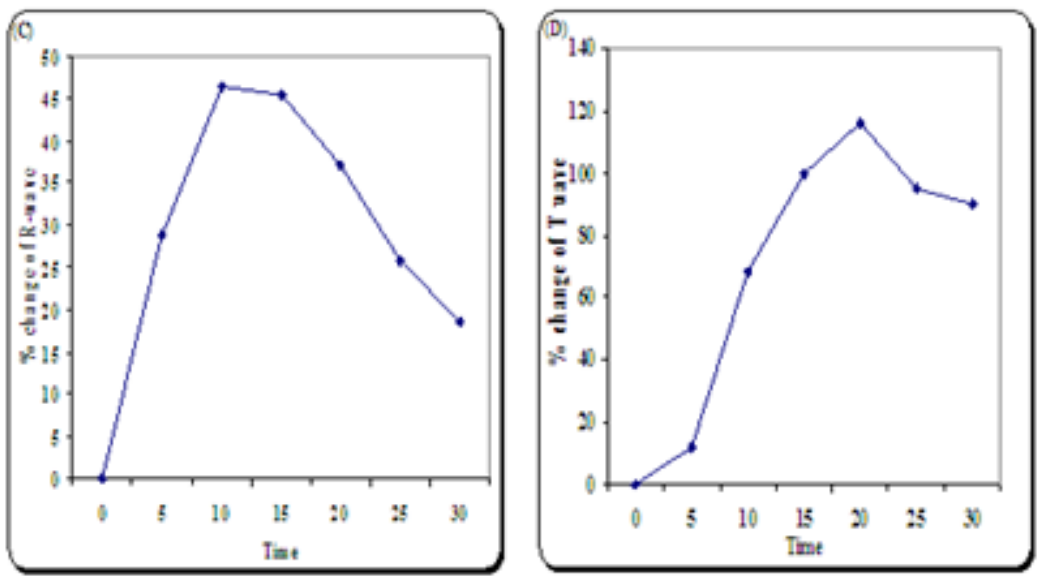

Figure1. Percentage of change of (A) heart rate and (B) P-R interval, (C) R amplitude, (D) T- amplitude of isolated toad's heart after perfusion with $5 \mu \mathrm{g} / \mathrm{ml}$ O. brevis extract. ( $\mathrm{n}=10 /$ group).

Table 2: Percentage of incidence of ECGs abnormalities recorded from isolated toad's heart after direct perfusion with $5 \mu \mathrm{g} / \mathrm{ml}$ of $O$. brevis extract (n=10/group).

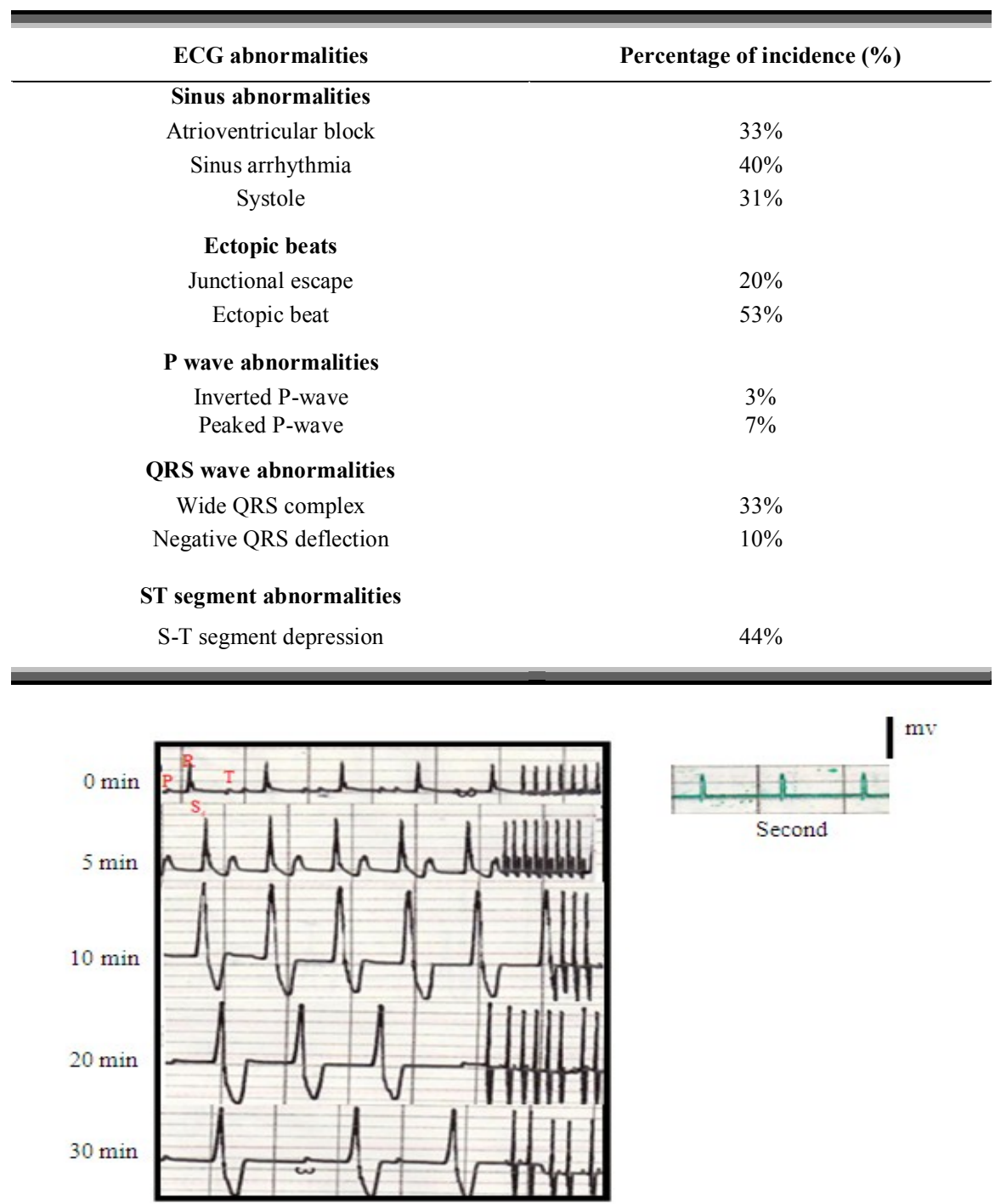

Plate 1: ECG traces showing the effect of direct perfusion of isolated toad's heart with $5 \mu \mathrm{g} / \mathrm{ml}$ of $O$. brevis extract on the electrocardiogram of isolated toad's heart at different time intervals. 

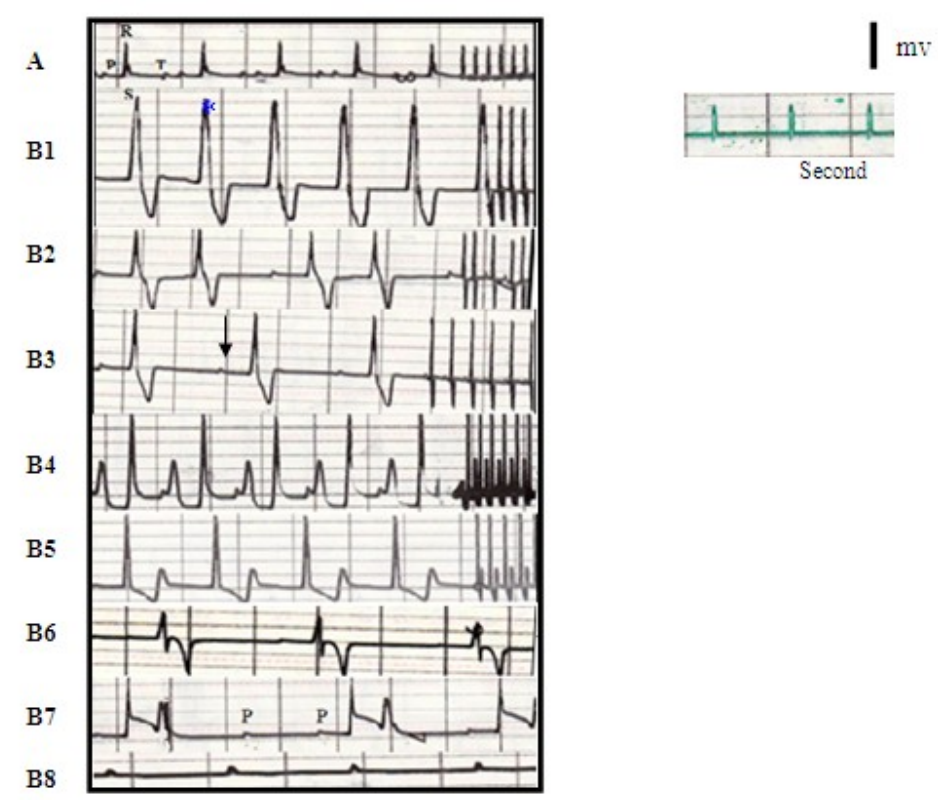

Plate 2: ECGs recorders showing examples of cardiac disorders induced by direct perfusion of isolated toad's
heart with $5 \mu \mathrm{g} / \mathrm{ml}$ of $O$. brevis extract.
A- Before treatment.
1- Wide QRS-Wave.
B- After treatment.
2- Sinus arrhythmia and *ST- segment depression.
3- First degree block
4- Peaked P- wave
5- Ectopic beats.
6- Negative QRS deflection
7- Second degree block
8- Complete heart block.
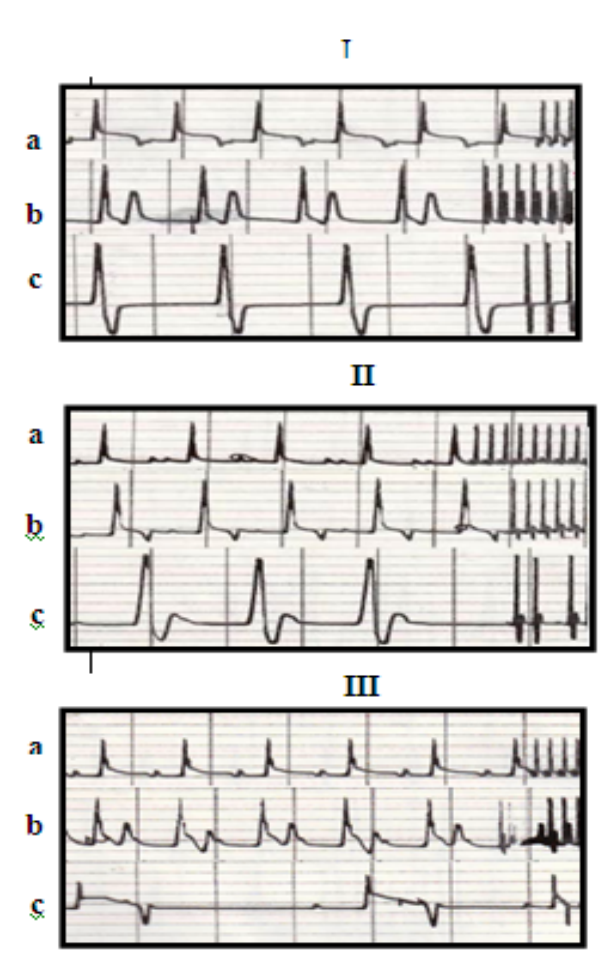

Plate 3: ECGs recordings showed the mechanism of $5 \mu \mathrm{g} / \mathrm{ml}$ $O$. brevis extract action on isolated hearts.

$\mathrm{I}-4 \mu \mathrm{g} / \mathrm{ml}$ of Atropine sulfate, II- $5 \mu \mathrm{g} / \mathrm{ml}$ of propranolol and III- $5 \mu \mathrm{g} / \mathrm{ml}$ of verapamil
a) Before treatment.
b) 10-min after treatment.
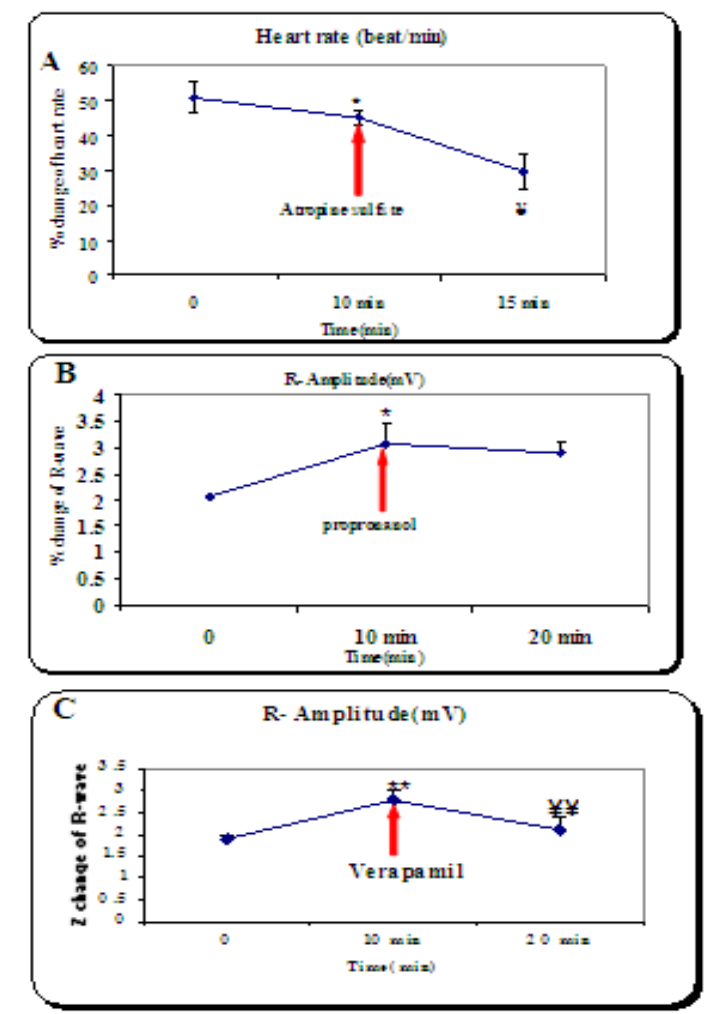

Figure2. Mechanism of action of $5 \mu \mathrm{g} / \mathrm{ml} O$. brevis extract on isolated heart. (A) $4 \mu \mathrm{g} / \mathrm{ml}$ of Atropine sulfate, (B) $5 \mu \mathrm{g} / \mathrm{ml}$ of propranolol and (C) $5 \mu \mathrm{g} / \mathrm{ml}$ of verapamil Values represent mean $\pm \mathrm{SD}(\mathrm{n}=5 /$ group$)$. *Significantly different from zero value by student's paired t-test ( $\mathrm{P}$ $<0.001)$. $¥$ Statistically different from the value before blockers application student's paired t-test 

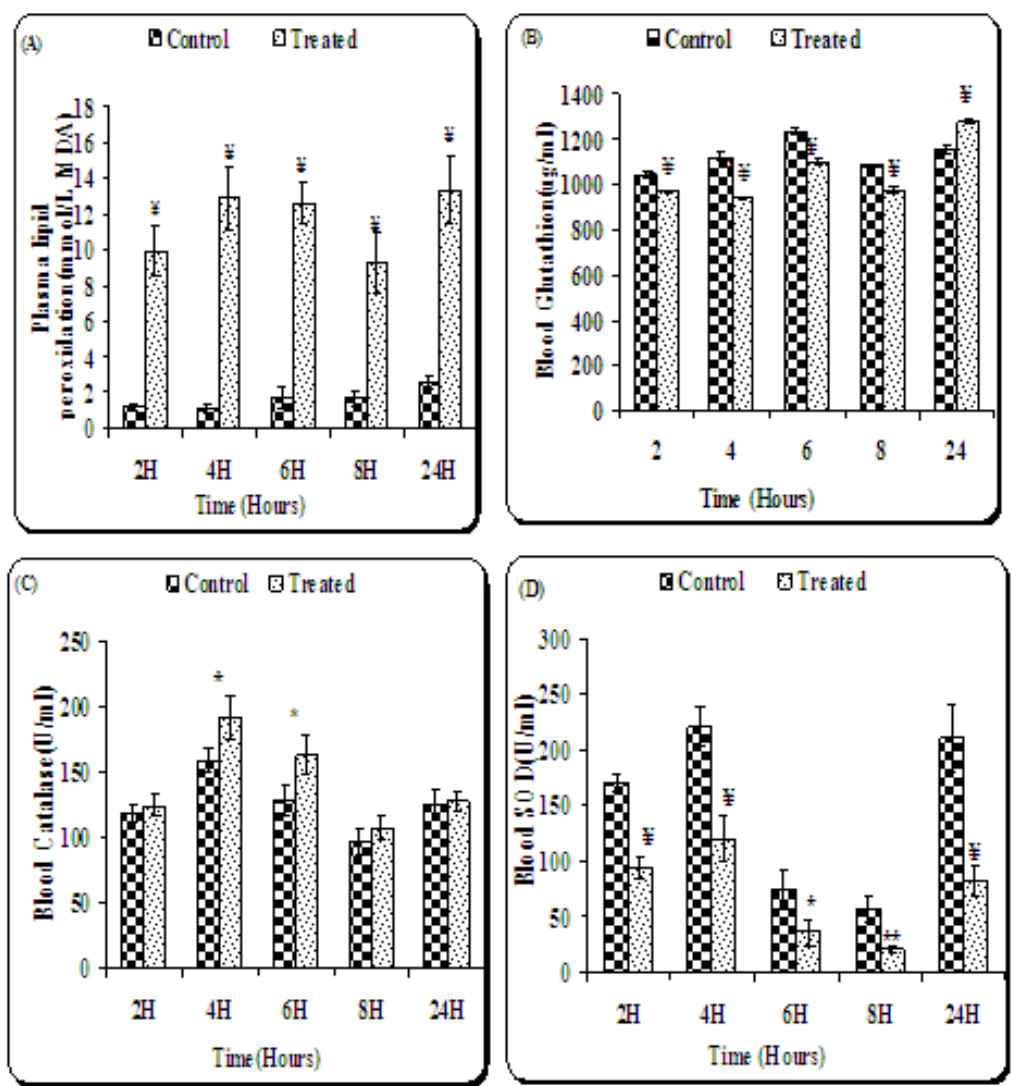

Figure 3. Effect of direct incubation of blood with $1 \mu \mathrm{g} / \mathrm{ml}$ O. brevis extract on (A) Plasma lipid peroxidation, (B) Blood glutathione. (C) Catalase and (D) Superoxide dismutase respectively. Values represent means \pm S.E $(\mathrm{n}=10$ / group $) *(\mathrm{P} \leq 0.05) * *(\mathrm{P} \leq 0.01) ¥(\mathrm{P} \leq 0.001)$, significantly different from control group, student's unpaired t-test. 